AWEJ for Translation \& Literary Studies, Volume3, Number4. October 2019

Pp.130-138

DOI: http://dx.doi.org/10.24093/awejtls/vol3no4.11

\title{
Teacher-Student Relationship in William Gibson's The Miracle Worker and George Bernard Shaw's Pygmalion
}

\author{
Falak Ibrahim Abbas \\ English Language Department, College of Languages and Translation \\ University of Jeddah, \\ Jeddah, Kingdom of Saudi Arabia
}

\begin{abstract}
:
The relationship between the teacher and the student is one of the most important pillars of education. It contributes to the success of the educational process and affects its outcomes. Following a feminist analysis of gender roles represented by the British writer and feminist Virginia Wolf in her book A Room of One's Own (1929), this study explores the teacher-student relationship in William Gibson's The Miracle worker (1959) and George Bernard Shaw's Pygmalion (1913). It investigates the role of the female teacher in comparison to the male teacher and the effect on each one's learner. However, to prove their ability to transform their students, each one has motivational techniques and styles of teaching. Henry Higgins, the male teacher in Pygmalion, uses his skill and knowledge as a phonetician while Annie Sullivan in The Miracle Worker uses her earlier experience as a blind child together with the information she acquired from Doctor Alexander Bell. This study concludes that females can provide first-class education even if they face unique challenges. Moreover, it becomes clear that the relationship between the teacher and the student in each work affects the student profoundly in every sense.

Keywords: female teacher, George Bernard Shaw, Helen Keller teacher/student relationship, a male teacher

Cites as: Abbas, F. I. (2019). Teacher-Student Relationship in William Gibson's The Miracle Worker and George Bernard Shaw's Pygmalion. Arab World English Journal for Translation \& Literary Studies3 (4)130-138 DOI: http://dx.doi.org/10.24093/awejtls/vol3no4.11
\end{abstract}

